Archived version from NCDOCKS Institutional Repository http://libres.uncg.edu/ir/asu/

\title{
Appalachľan
}

B O O N E, N O R T H C A R O L I N A

\section{Preparing Students For Research And For Work With The Transgender Population: Exploring The Results Of An Innovative Course Pairing}

\author{
By: Denise L. Levy, Gail Leedy, and Geri Miller
}

\begin{abstract}
In an effort to provide opportunities for social work students to develop competencies for research and for working with transgender individuals, the authors paired content in two separate undergraduate courses: cultural competence and research methods. A qualitative research study was designed to assess the impact of this curricular approach. Following completion of the two courses, students participated in focus groups to discuss their experiences and what they learned through the unique course pairing. Analysis of the focus group transcripts revealed that students developed new understanding and knowledge related to research, the transgender population, attitudes about this population, and how to advocate for this population.
\end{abstract}

Denise L. Levy, Gail Leedy \& Geri Miller (2013) Preparing Students for Research and for Work with the Transgender Population: Exploring the Results of an Innovative Course Pairing, Journal of Gay \& Lesbian Social Services, 25:3, 306-325, DOI: 10.1080/10538720.2013.806879. Publisher version of record available at: https://www.tandfonline.com/doi/full/10.1080/10538720.2013.806879 
Journal of Gay \& Lesbian Social Services

\section{Preparing Students for Research and for Work with the Transgender Population: Exploring the Results of an Innovative Course Pairing}

Denise L. Levy , Gail Leedy \& Geri Miller

To cite this article: Denise L. Levy , Gail Leedy \& Geri Miller (2013) Preparing Students for Research and for Work with the Transgender Population: Exploring the Results of an Innovative Course Pairing, Journal of Gay \& Lesbian Social Services, 25:3, 306-325, DOI: 10.1080/10538720.2013.806879

To link to this article: http://dx.doi.org/10.1080/10538720.2013.806879 


\title{
Preparing Students for Research and for Work with the Transgender Population: Exploring the Results of an Innovative Course Pairing
}

\author{
DENISE L. LEVY \\ Appalachian State University, Boone, North Carolina \\ GAIL LEEDY \\ New Mexico State University, Albuquerque, New Mexico \\ GERI MILLER \\ Appalachian State University, Boone, North Carolina
}

\begin{abstract}
In an effort to provide opportunities for social work students to develop competencies for research and for working with transgender individuals, the authors paired content in two separate undergraduate courses: cultural competence and research methods. A qualitative research study was designed to assess the impact of this curricular approach. Following completion of the two courses, students participated in focus groups to discuss their experiences and what they learned through the unique course pairing. Analysis of the focus group transcripts revealed that students developed new understanding and knowledge related to research, the transgender population, attitudes about this population, and how to advocate for this population.
\end{abstract}

KEYWORDS transgender, experiential learning, teaching, social work, research, cultural competence

\section{INTRODUCTION}

The Council on Social Work Education's (CSWE, 2008) Educational Policy and Accreditation Standards charge social work programs with the task of educating students using a competency-based approach. Students are required to demonstrate competency in "research-informed practice and practice-informed research" (p. 5). In addition, students must "engage diversity and difference in practice" (CSWE, 2008, p. 4) and "advance human rights 
and social and economic justice" (CSWE, p. 5). In this article, the authors discuss an innovative pairing of two undergraduate courses: a cultural competence course and a research methods course. This curricular modification infused content on knowledge, attitudes, and skills for culturally competent practice with the transgender population in both courses. Using qualitative methods, we then explored the impact of this design on student attitudes towards gender nonconformity, research methods, and cultural competency.

Although content on gay and lesbian populations has become more prominent in the social work curriculum, information about the transgender population continues to be neglected, overshadowed, or even subsumed by an emphasis on sexual orientation (Erich, Boutté-Queen, Donnelly, \& Tittsworth, 2007; Fredriksen-Goldsen, Woodford, Luke, \& Gutiérrez, 2011; McPhail, 2008). Fredriksen-Goldsen and colleagues found that social work faculty in both Canada and the United States were less supportive of including content related to transgender issues compared to content on sexual orientation.

Still, social work students should receive specific instruction on gender identity and experiences of the transgender population (Burdge, 2007; Case, Stewart, \& Tittsworth, 2009; Erich et al., 2007; McPhail, 2008). Several authors have discussed beginning ideas on how to accomplish this. For instance, Burdge (2007) encourages social workers to challenge the concept of gender itself, especially the current binary system, while McPhail (2008) calls for a "re-gendering" of the social work curriculum. Nagoshi and Brzuzy (2010) suggest that transgender theory can assist social workers in understanding that "empowerment is derived from the mind and body dynamically working together to transcend social constructs of gender or any other social category" (p. 440). These perspectives are based on the importance of revisioning gender in order to promote social justice for those who are oppressed due to rigidly applied gender categories.

Students who learn this content are more likely to have the desire, knowledge, and competency to serve transgender individuals (Erich et al., 2007). Although studies in Poland (Antoszewski, Kasielska, Jędrzejcsak, \& Kurk-Jeromin, 2007) and Hong Kong (Winter, Webster, \& Cheung, 2008) reveal basic knowledge of transgender identity among students, social work students in the United States report a lack of educational content related to the transgender population (Erich et al., 2007). Both Erich and colleagues (2007) and McPhail (2008) suggest infusing new concepts of gender and information on the transgender population into the social work curriculum.

\section{LITERATURE REVIEW}

\section{Teaching Cultural Competence}

Assisting students in developing cultural competence is an important component of the missions of the helping professions, including nursing 
(Campinha-Bacote, 2002), medicine (Betancourt, 2006), psychology (Sehgal et al., 2011), education (Wallace, 2000), counseling (Hipolito-Delgado, Cook, Avrus, \& Bonham, 2011), and social work (Warde, 2012). Social work programs teach cultural competence in many different ways (Guy-Walls, 2007). Culture and diversity are often infused throughout the curriculum through experiential education and self-examination (Armour, Bain, \& Rubio, 2004). Instructors may also rely on activities to induce self-awareness, empathy toward underrepresented groups, and an understanding of power and privilege (Colvin-Burque, Zugazaga, \& Davis-Maye, 2007). For instance, one model, the Self and Others Awareness Project (SOAP), guides students in a linear fashion through a process of self-discovery, including small group exercises that highlight both the sameness and differentness of the students (Colvin-Burque et al., 2007). Once a class has developed a sense of cohesiveness, additional assignments consist of journals, guest speakers, videos, and lens-person assignments.

Classroom games are also employed by social work instructors in teaching about cultural diversity (Lichtenwalter \& Baker, 2010). Students learning through game-based activities are often more engaged and tend to retain the information over a longer period of time, according to Ebner and Holzinger (2007). When using game-based learning, it is critical that instructors include discussion and refection along with the games (Cruz \& Patterson, 2005).

In addition to experiential, in-class activities, some instructors find that interactive chat rooms are helpful to students in cultural competence courses because they provide opportunities to address diversity in a more structured and semi-private setting (Van Soest, Canon, \& Grant, 2000). In employing this technique, it is critical that instructors stay involved in order to monitor content for any disrespectful or disparaging statements and to correct any misconceptions. Although a study of this teaching method revealed that students and instructors found both positive and negative aspects of the Web site, it was found to be a useful tool overall (Van Soest et al., 2000).

\section{Teaching Transgender Content}

Because most undergraduate social work programs cannot devote an entire course to working with the transgender population, the authors elected to infuse transgender content into two undergraduate courses on research methods and cultural competence. As described by Van Den Bergh and Crisp (2004), the courses incorporated the "trilogy of attitudes, knowledge, and skills" (p. 236) for practice with the transgender population.

\section{KNOWLEDGE}

Key areas for knowledge development were identified beginning with several definitions. According to Denny, Green, and Cole (2007), gender identity 
refers to how individuals conceive of themselves on a continuum of masculine to feminine. In examining transgender identity, the word "transgender" conveys many complex meanings. Teich (2012) explained that transgender is an umbrella term which encompasses various groups of people (gender queer, gender variant, cross-dressers, transsexual individuals, and so forth) who feel that their gender does not match their birth-labeled sex.

Second, because people who identify as transgender are often part of a hidden minority, the courses included demographic information as described by Rosser, Oakes, Bockting, and Miner (2007). These authors report on data from almost 1,300 respondents, representing all states except Montana and South Dakota, and including male-to-female (MTF) and female-to-male (FTM) transsexuals, drag kings and queens, cross-dressers and transgender individuals. Compared to the demographics of the United States overall, the participants were less diverse in terms of race and ethnicity, were better educated, had lower average household incomes, were more likely to be single, and were less likely to claim a religious affiliation.

Theories of gender identity formation and expression were also included. Contrary to the predominant thinking of the 1960s and 1970s, gender identity is not solely a product of social and environmental influences. Rather, as reviewed by Bao and Swaab (2011), sexual differentiation of areas of the brain can be affected by many factors including genetics, intrauterine hormone levels, hormone receptor levels, and autoimmune factors. Due to these complex interactions, it is possible for an individual's gender identity to contradict the sex assigned at birth, their genetic sex, their genitalia, and the gender roles assigned to him or her by society (Bao \& Swaab, 2011).

\section{AtTITUdes}

As a means to inform students' attitudes towards the transgender population, the actual experiences of transgender people were incorporated into these two courses. One of the courses included a panel presentation by several transgender individuals. Panel presentation and guest speakers are commonly utilized in order to expose students to experiences of oppressed groups (Kwon \& Hugelshofer, 2012).

In addition to information gained from attending the panel presentation, students learned that discrimination toward gender-nonconforming individuals has been reported in health care (Dean et al., 2000), the workplace (Berry, McGuffee, Rush, \& Columbus, 2003; Dispenza, Watson, Chung, \& Brack, 2012), higher education (Case, Kanenberg, Erich, \& Tittsworth, 2012) and the military (Kerrigan, 2012). Reports by transgender individuals of their experiences of violence were also provided (Cook-Daniels \& Munson, 2010; Lombardi, Wilchins, Priesing, \& Malouf, 2001; Singh \& McKleroy, 2011). For example, Lombardi and colleagues (2001) found that among 400 respondents, more than one-half reported verbal harassment, approximately one 
in four reported a violent incident, and one in three reported economic discrimination. Rape or attempted rape was reported by $14 \%$ and other types of physical assaults were reported by 19\%. Finally, Stotzer (2009) provided national-level data which confirmed high levels of sexual, physical, and verbal violence against transgender people. Stotzer's report indicated that violence begins early in life and is often repeated across the life span. The highest level of vulnerability is experienced by those who are younger (Clements-Nolle, Marx, \& Katz, 2006; Grossman \& D'Augelli, 2007). Grossman and D'Augelli (2006) provide a rich picture of the lives of young adults who identify as transgender. As teenagers, they experienced a lack of available and accessible services as well as discrimination, harassment, and victimization. The need for medical care and for support from family and friends contributed to the vulnerability of these individuals.

Of particular interest to social work students was research related to mental health of transgender people. Diagnoses commonly encountered include post-traumatic stress disorder (PTSD) and other anxiety disorders, depression, and adjustment disorders (Dean et al., 2000). Based on a sample of more than 500 ethnically diverse, transgender individuals in the San Francisco area, Clements-Nolle and colleagues (2006) found that almost one-third had attempted suicide. Furthermore, participants reported high rates of alcohol or drug treatment (28\%), depression (60\%), and low self-esteem. The authors were able to determine that discrimination, rather than low selfesteem or mental health issues, mediated the high rate of suicide attempts. Indeed, 59\% of the respondents reported rape or forced sexual activity, 36\% reported physical harassment, and 83\% reported verbal harassment.

In addition, students need to understand the source of these acts of discrimination and violence. Transphobia has been defined by Hill and Willoughby (2005) as "an emotional disgust toward individuals who do not conform to society's gender expectations" (p. 533). Studies on transphobia itself are relatively rare. In order to examine discrimination and violence, Hill and Willoughby (2005) developed scales of transphobia and genderism which were then tested using a sample of adults living in Montreal, a city that is "well-renowned for its liberal attitudes toward sexuality and gender issues" (p. 452). In spite of this setting, they concluded that negative attitudes toward transgender individuals are not rare, but rather are easy to elicit.

SKILLS

Interviewing skills are most commonly developed in practice courses. However, there are opportunities to incorporate skill building into other parts of the curriculum. In both courses, students practice interview skills inside and outside of class, and interviews included topics related to gender identity. Students in the cultural competence course discussed micro, mezzo, and macro interventions appropriate to transgender clients. In addition, they 
identified best practices to ensure that social service agencies are welcoming to diverse clients, including transgender clients.

\section{Teaching Research Methods}

Teaching research methods can be both challenging and rewarding for students as well as instructors. There is considerable data on student attitudes toward research courses in the social work curriculum. Although many social work students express anxiety when beginning their research courses, stereotyping them as "research reluctant" is an oversimplification. For instance, Secret, Rompf, and Ford (2003) reported a wide range of initial attitudes toward research. According to their work, many students do not express a fear of research, and they even indicate that they find research to be useful and appealing. A second study (Maschi, Bradley, Youdin, Killian, Cleaveland, \& Barbera, 2007) found that students' anxiety decreased and positive thoughts toward research increased after taking the course but their satisfaction with the research process itself actually decreased. This study did not provide specific information on what the students did in the research course other than indicating that they conducted research and wrote up a final report.

Although many undergraduate programs do not require social work students to complete a research project, faculty teaching research methods often agree that this experience will reinforce concepts discussed in class and greatly enhance students' knowledge (Lundahl, 2008; Rubin, Valutis, \& Robinson, 2010). Reluctance to require students to conduct research can be partially attributed to the following barriers: faculty perceptions of their research competence, institutional issues, beliefs that students are not ready to conduct their own research, and lack of time. Lundahl (2008) suggests that having students engage in a single project, rather than each student conducting his or her own, can minimize these barriers while also increasing student satisfaction with the process.

\section{Infusing Transgender Content into Two Courses}

The current literature on preparing students for culturally competent work with the transgender population is substantial. Furthermore, many cultural competence courses include such content. However, isolating content to one course may not be best. Social work research courses may represent a viable additional pathway for gaining competence with marginalized populations. Recently, Vincent (2012) conducted a study with social work research instructors to determine how social justice topics are integrated into a research course. His findings indicated that instructors are supportive of integrating such content, yet their coverage is seldom theoretically based nor is it specific. 
In accordance with Vincent's (2012) recommendation that those who teach social work research courses should "augment traditional pedagogy such as lectures and class discussion with the innovative use of multimedia and experiential exercises" (p. 220), the focus for the present study was the linking of content on cultural competence for a specific marginalized population in two distinct courses: a cultural competency course and a research methods course. The social work research course was designed to spotlight the oppression and discrimination experienced by transgender individuals.

Theoretically, both the research methods and cultural competence courses were based on experiential education, or the idea that "we do not learn directly from the world, or directly from what we are taught; we learn from our experience of the world and our experience of what we are taught" (Jarvis, 2006, p. 197). The courses incorporated several experiential assignments in order to promote transformational learning. Transformational learning theory, proposed by Mezirow (1991), explains that individuals can be transformed by what they learn. The curriculum was designed with transformational learning theory in mind, providing opportunities for disorienting dilemmas, critical reflection, discussion, and action.

\section{DESCRIPTION OF THE INNOVATIVE COURSE PAIRING}

\section{Context}

Integrating material on sexual minorities into a more holistic curriculum framework requires attention to the unique setting of the educational program and the community and the characteristics of the faculty and the student body (Gezinski, 2009). Because of the relative lack of knowledge regarding gender nonconformity coupled with transphobia (Hill \& Willoughby, 2005), we determined that content specific to transgender populations and issues would require exceptional sensitivity to context (Mallon, 1999).

This study was conducted in a Master's-Level public university (Carnegie Foundation, 2010), with a student population of more than 17,000. The study region, defined here as the county in which the university resides plus the six contiguous counties, has several important characteristics. First, it is a geographically distinct region which is located within the Appalachian Mountains. It is rural, with just over a quarter of a million people and no city with more than 50,000 within the 2,500-square-mile area, which adds a level of complexity to the context (Walinsky \& Whitcomb, 2010). It also has low racial and ethnic diversity. According to the 2010 census, the population is $90 \%$ white non-Hispanic, compared to $65 \%$ white non-Hispanic for the state as a whole (United States Census Bureau, 2011). Another important characteristic of this region is the religious profile. According to the Association of Religion Archives report of 2010, within the region, 79\% regularly attend church and $41 \%$ of the total population are members of Evangelical 
Protestant congregations (http://www.thearda.com). For comparison, the figures for the state as a whole are 57\% and 27\%, respectively. For the United States, only 33\% of those who regularly attend church identify as Evangelical Protestants, and only 16\% of the total population are Evangelical Protestants (Association of Religion Archives). Thus, this rural region is dominated by a single religious perspective and one which is considered conservative. In sum, as described by Behringer and Friedell (2006), "the mountains shape people's lives, both literally and figuratively. There is clearly a distinguishable Appalachian culture, and 'place' is a prominent feature in that culture" (Conclusion section, para. 1). This "place" was an important consideration both in deciding to focus on competencies for working with the transgender population and in determining the curricular approach.

\section{Curriculum Design}

In discussing strategies for assisting students in developing cultural competence for work with the transgender population and for advocating for this population, the authors decided to pair two courses to provide a more holistic approach (Gezinski, 2009). As discussed previously, the two courses incorporated concepts from experiential education and transformational learning theory. In addition to attending a panel presentation by local transgender individuals, students learned basic information about the transgender population, including terminology, unique experiences, and possible social work interventions related to this community. A key component to this course pairing was a mixed-methods study conducted by the students which focused on the attitudes of people living within the region toward the transgender population.

\section{Cultural Competence Course}

Many of the best practices identified in the literature and previously reviewed were employed in the cultural competence course discussed here. In this course, it is important to develop a safe and respectful space for meaningful discussion to occur. Students create their own list of student rights and responsibilities as well as behavioral indicators of a respectful classroom at the beginning of the semester. Class meetings include lectures, experiential activities, discussions, and role-plays. The course begins with overarching, general concepts such as human rights and advocacy, and then moves into discussions and information around specific populations. Although concepts related to the transgender population are infused throughout the entire semester, there are at least two class periods devoted solely to gender identity and expression. In this course, students are encouraged to "reflect on their own experiences of privilege and discrimination [in order to] help them to better understand the lived experience of others" (Ancis \& Ali, 2005, p. 96). 
This cultural competence class focused on enhancing students' overall awareness and sensitivity to the transgender population with the hope of facilitating increased effectiveness of the students in their future work as generalist practitioners. In addition, the class was geared toward increasing students' motivation to advocate for policies which eliminate discrimination toward the transgender population.

\title{
Research Methods Course
}

The instructor used a collaborative approach to research design and execution. In the early part of the course, the instructor provided an overview of the research process and assisted students in developing a research question and design based on their own interests. By the middle of the semester, the instructor transitioned the class to develop and conduct research on transphobia. The rationale for this topic was based on the recommendation of Gabbard, Starks, Jaggers, and Cappiccie (2011):

\begin{abstract}
Social work educators owe it to their students not only to teach them the pertinent history, values, and customs of oppressed and marginalized groups; they also need to put them into situations where they are forced to directly encounter and empathize with the negative forces of racism, bigotry, homophobia, ethnocentrism, and gender bias which plague their clients every day. (p. 207)
\end{abstract}

By gathering data on transphobia, students would see directly the degree to which negative attitudes toward gender nonconformity exist within the region.

After the topic was introduced, students read research articles on transphobia and gender nonconformity. Midway through the semester, a panel of four students representing gender nonconformity and the transgender community spoke to the class and engaged in an open discussion period with the students. The class then developed two interrelated research studies, one quantitative and one qualitative. For the quantitative study, students developed a questionnaire which asked for limited demographic information including age, education, gender, religious affiliation, commitment to religious community, and place of residence. The transphobia scale developed by Hill and Willoughby (2005) was included. Each student distributed surveys to at least six area residents, with the goal of having a range of ages. For the qualitative study, three of the students interviewed one person regarding his or her thoughts, perceptions, and feelings toward transgender people.

All students participated in data analysis. Students entered the quantitative data into files for analysis with SPSS. Basic statistical analyses were conducted, including correlations comparisons of means. In addition, the data collected by the students were also compared to data collected by the research instructor in another region of the country. These data were 
collected in much the same way as the data collected by the students in this study. The participants in the previous study were from a small city in a very sparsely populated area of the mountain west region of the United States. From these analyses, the students learned that the transphobia levels were higher in their study population than were those from the mountain west population.

For the qualitative aspect of the project, students transcribed their interviews and shared their results with the rest of the class. The students coded the transcripts and analyzed the data for themes regarding attitudes and perceptions of transgender. All students wrote a final paper that included their methods, results, and discussion/conclusions.

\section{Evaluation of the Course Pairing}

At the end of the semester, a qualitative study was conducted to explore the undergraduate social work students' responses to the innovative course pairing. Two research questions guided this study. First, how does completing a research project focused on a marginalized population assist students in learning about research? Second, what aspects of these courses do students identify as most helpful in preparing them for work with the transgender population? This study was approved by the institutional review board.

\section{METHODS}

\section{Data Collection}

At the end of the semester, students were invited to take part in a focus group to discuss their experiences. The term focus group was originally developed to describe situations where the interviewer or moderator asks the members of the group specific topical questions following research (Merton, Fiske, \& Kendall, 1956). The focus groups allowed the students to discuss their experiences in the two courses, to "complete" the research experience, and to "tell their stories" (Morse, 1994). In this regard, one of the participants stated, "I have all these feelings for myself, but being able to hear other people's viewpoints on the class and everything that we learned about was a nice opportunity and a good way to end the class."

A focus group moderator needs to be "flexible, objective, empathic, persuasive, a good listener" (Fontana \& Frey, 1994, p. 265). Furthermore, when students are the participants, special care must be taken to ensure safety and comfort. Based on these needs, the chosen moderator was a counselor of 30 years who was not known to the students and who would not be a part of their future education. The students were informed that no social work faculty members would view the videotapes at any time. The focus group moderator used an unstructured process, and began the groups 
by asking the general question, "What do you want to tell us about your experience as it relates to doing research regarding discrimination towards the transgender population?"

\section{Participants}

Twenty undergraduate social work students were enrolled in the research course, and 14 were concurrently enrolled in the cultural competence course. Nineteen students voluntarily participated in focus groups, and 17 of these were females less than 25 years old. Students signed up for one of three focus groups based on their availability, resulting in groups of five, six, and eight participants. The focus groups lasted 50 minutes and were videotaped. The tapes were transcribed by a graduate assistant and subsequently erased. In order to protect the confidentiality of the students, transcripts only included pseudonyms, all identifying information was removed, and the social work researchers did not view the tapes.

\section{Data Analysis}

Transcripts were analyzed by one of the authors and were coded line-byline, grouping the codes into categories and constantly comparing the data. According to Ezzy (2002), this form of analysis allows data to be grouped and differentiated. The other two authors then reviewed the coded transcripts and provided comments and suggestions. Finally, using peer examination, all three authors reviewed the final coded transcripts to ensure validity in the analytic process.

\section{RESULTS}

Analysis of the focus group transcripts revealed that students developed new understanding and knowledge related to research, the transgender population, attitudes about this population, and how to advocate for this population. Each category is outlined next, and includes quotes from the focus groups.

\section{Learning About Research}

Students were initially daunted by the idea of completing their own research project on an unfamiliar topic. However, several expressed that it was helpful to work on a project that was already designed. Some mentioned that they "liked having a focus to the class, something to always relate back to." As the project progressed and students learned more about the transgender population, they reported becoming more comfortable with the project. Furthermore, by the time the project ended and it was time to analyze the quantitative results, it had become "interesting." As one student stated, 
"I thought of [research] as more cut and dry than it is; I think the main thing that I really learned from the research was the variety of feelings about [the transgender population]."

Because some of the students collected qualitative data and others collected quantitative data, they were able to learn about both types of data collection and analysis. Overall, students felt that qualitative interviews were more "intrusive" and "invasive" than quantitative surveys. However, they explained that they were able to get richer data from these interviews. For example, one student explained that several survey respondents changed their answers, and that an interview would aid in understanding what that means.

They also indicated that they learned about their own biases as researchers: "[We were] almost working to fight against the stereotypes of the harassment or whether or not people feel violent toward [the transgender population] when at the same time we were putting our own stereotypes on the people we were surveying."

The students also made the connection between learning and conducting research and the need for cultural competency. One exchange between students exemplified this:

Student A: I felt like I could not go out and do research, but I could go out and work with a transgender community and be culturally competent. Student B: I actually feel we learned a lot about research and it's just that whatever group you do research with, whatever population, you are going to learn to be culturally component with them as you go, so we had to learn that anyway.

\section{Learning About the Transgender Population}

Students explained that they learned a great deal about the transgender population through this project. Many students had not "talked about or learned much about" the population before taking these two courses. One explained that she "did not even know what transgender meant" before this semester and has now "become more open-minded." Another said that she "thought it was a joke" and now understands that it is "really a way of life for some individuals." A final student put it this way: "Now that we have done this research, in the future, if I do have to work with someone who is transgender, I would know how to handle it better and be able to work with them better."

Having transgender speakers in class was an important part of this learning. First, it assisted students in putting a face to the transgender population. One student explained that this was "most helpful, being able to ask questions to people who identify as transgender." Another echoed this idea: 
It's always good to have someone from the group instead of [learning about] the idea of it. When you see that it's actually a person, who has thoughts and feelings ... and is there connected with you, it always makes everything much more comfortable.

Second, the guest speakers taught students about correct terminology to use with this population. Students explained that they learned that it is appropriate to ask individuals about which pronouns they prefer. Finally, students reported that interacting with transgender individuals led them to question some of their initial assumptions about this population.

Three students, though, expressed discomfort in interacting with the guest speakers; they were unsure what questions to ask and did not want to offend the speakers. One student explained: "I felt uncomfortable not because they were people who were transgender, but because I didn't know what boundaries I could cross. ... I was just so afraid that I was going to cross a line and they were going to say 'that's too personal' [of a question]." These three found the class "tense," "awkward," and "uncomfortable." However, in the end, they also "came out of this class with a better understanding and more knowledge of the transgender population."

\section{Learning About Transphobia}

The students were surprised by their analysis of the data especially when they learned that the participants from their region were less accepting than those from a previous study. One student explained that these results were "kind of depressing" and "sad." Another "took it as a challenge because as social workers we have got so much work to do ... it's up to us to make that change, to advocate for what we believe in." Another student noted, "Reading the surveys that we sent out and some of the information that people would write on that, I took a step back to see how brutal that some people could be when it came to accepting a population that was different from themselves."

In addition, several explained that what they "gained the most [from this project] was the variety of opinions and feelings" about the transgender population. In fact, the data challenged their assumptions and stereotypes regarding the influence of demographic factors such as political affiliation, religion, and age, on transphobia. For example, one student said that she "assumed that older people would be less open to [the transgender population] as the younger generations, but in the surveys that I actually analyzed, it was for the most part the opposite of that." Another student explained that she assumed that conservatives would not be as accepting of the transgender population, but found that attitudes differ from person to person. "The irony was that we were looking at the stereotypes towards the transgender population and we all were using our own stereotypes ... of the people we were 
actually surveying." In general, all of the students found their stereotypes challenged through this project.

\section{Advocating for the Transgender Population}

Inevitably, students were asked questions by community members while completing their mixed-methods study. Students completing both quantitative and qualitative data collection expressed discomfort in educating others about the transgender population. In general, they were focused on not wanting to offend their participants or "push people" who were uneasy. Students were careful not to "step on anybody's toes or cross any lines." In addition, when their participants made negative or "judgmental" remarks about the transgender population, students ignored their comments.

For those completing qualitative interviews, which students identified as more intrusive than quantitative surveys, it was easier to interview participants who already had significant knowledge about the transgender population. One student explained that her "perfect, easy" interviewee "had actually done a couple of projects on the transgender community ... and was very informed on the topic." Another student said that she felt like she was teaching her interviewee, who knew little about the transgender community. Another stated, "I think that people should be educated about all these things and should be aware of them and should not discriminate against anybody."

\section{Curriculum Integration}

Although none of the students directly commented on the links between the cultural competence and the research methods courses, students did make the connection to the goal of cultural competence overall. One student compared her experiences with cultural diversity within her major to her friend who was majoring in business: "You know, it's just like a whole different world, and what we are exposed to is just a lot different than other college students, I think." Not all students were favorable, though. One student was particularly direct in her observations:

I felt like that [transgender issues] was ... the only thing we ever talked about or covered in our classes ... it was just one thing after another and I was just like there are other populations and other things in social work that social workers focus on and I just don't understand why this semester that's the only thing I felt like the social work department is focusing on. 


\section{DISCUSSION AND IMPLICATIONS}

\section{Implications for CSWE's Competencies}

At the beginning of this article, we mentioned three competencies that relate to this study: engaging in "research-informed practice and practice-informed research," "engaging diversity and difference in practice," and "advancing human rights and social and economic justice" (CSWE, 2008, pp. 4-5). Through this project, students had several opportunities to demonstrate competency in these areas. Based on experiential education and transformational learning theory, the authors found that demonstrating through doing, reflecting, and discussing was much more meaningful and useful for both students and instructors. Students finished this project expressing a desire to learn more and voicing additional questions for contemplation. This desire for continued education is one that we rarely find after traditional research courses.

\section{Implications for Teaching Cultural Competence}

The majority of the students participating in this study were concurrently enrolled in a social work course on cultural competence. For students undertaking a research project about attitudes regarding the transgender population, it was very important to have a foundational knowledge about this population and be exposed to members of this population. The first implication for teaching cultural competence and diversity in social work programs is that experiential learning is an important tool. Interacting with diverse populations and completing research about these populations can build upon theoretical knowledge. Students explained that experiential activities were more helpful than just talking about a subject and all of the students identified substantial shifts in their understanding about the transgender population through this project. Therefore, in teaching cultural diversity, instructors should provide both theoretical knowledge and experiential activities in order to adequately prepare students for social work practice with diverse populations.

A second implication for teaching cultural competence involved students' ability to challenge oppression. Although they were completing a research project and it was important to maintain a neutral attitude, all of the students expressed some discomfort in interacting with people around the topic of transgender identity. According to the National Association of Social Workers (1999), social workers are called upon to end oppression, promote social justice, and challenge injustice. In accomplishing these tasks, students will need to become comfortable in talking about controversial topics, advocating for and with marginalized populations, and educating others around issues of diversity. Cultural competence courses should include practical and experiential exercises which will enable students to become comfortable with these tasks. 
A final implication is that cultural competence is not limited to one course. In fact, many social work programs infuse diversity across the curriculum in order to reinforce these concepts. In particular, this project highlights ways in which diversity and research go hand-in-hand.

\section{Implications for Teaching Research Methods}

This project also provides implications for teaching research methods. First, as mentioned earlier, experiential learning is imperative for undergraduate social work students. Students explained that they learned more about research through doing it than they ever would have learned by hearing or discussing in class. This project enabled students to better understand the role of research in social work practice, and reinforced the importance of research to understand individuals and communities.

A final implication for teaching research methods, which is related to the first, is that it is important to integrate both qualitative and quantitative methodologies into research conducted by students. Students were able to identify the benefits and limitations of both approaches based on the purpose of a study. Furthermore, they were able to complete initial analyses based on their results, and thus had the experience of doing both qualitative and quantitative analysis. Students were particularly enthusiastic when it came to this part of the project. It should be noted that students did not robustly embrace research at the end of the project, and this has been reported by others (Maschi et al., 2007).

\section{Limitations}

As with all studies, this study did have limitations. Only 19 of the 20 students in the research course participated in the focus groups, and only 14 of the students were simultaneously enrolled in the diversity course. This overlap of course work for only some of the students makes it difficult to sort out the effects of the combined courses. In addition, these social work students may have limited their discussion in the focus groups in order to appear more accepting and culturally competent. Although the data from the focus groups did show that the students had learned a substantial amount about research and about the transgender population from this project, this study does not include any longitudinal data, used a convenience sample, and is not generalizable. In addition to these limitations, the study had several strengths. For instance, using peer examination, all three authors reviewed the transcripts to ensure validity in the analytic process.

\section{CONCLUSIONS}

In conclusion, this project provided a way for students to learn about research methods and diverse populations while simultaneously demonstrating 
at least three of CSWE's (2008) competencies. The instructors developed a complimentary method for uniting content across two courses and provided students opportunities to develop the knowledge, values, and skills necessary to be culturally competent social workers with the transgender population. Additional research into the blend of these courses is needed, and future research should attend to the limitations of this study by including longitudinal data as well as ensuring that all students take these courses concurrently. Finally, subsequent studies could include projects related to other marginalized populations served by social work practitioners.

\section{REFERENCES}

Ancis, J. R., \& Ali, S. R. (2005). Multicultural counseling training approaches: Implications for pedagogy. In C. Z. Enns \& A. L. Sinacore (Eds.), Teaching and social justice: Integrating multicultural and feminist theories in the classroom (pp. 85-97). Washington, DC: American Psychological Association.

Antoszewski, B., Kasielska, A., Jędrzejcsak, M., \& Kurk-Jeromin, J. (2007). Knowledge of and attitude toward transsexualism among college students. Sex Disabilities, 25, 29-35.

Armour, P., Bain, B., \& Rubio, R. (2004). An evaluation study of diversity training for field instructors: A collaborative approach to enhancing cultural competence. Journal of Social Work Education, 40, 27-37.

Bao, A-M., \& Swaab, D. F. (2011). Sexual differentiation of the human brain: Relation to gender identity, sexual orientation and neuropsychiatric disorders. Frontiers in Neuroendocrinology, 32, 214-226.

Behringer, B., \& Friedell, G. H. (2006). Appalachia: Where place matters in health. Preventing Chronic Disease, 3, A113. Retrieved from http://www.cdc.gov/ pcd/issues/2006/oct/06_0067.htm

Berry, P. E., McGuffee, K. M., Rush, J. P., \& Columbus, S. (2003). Discrimination in the workplace: The firing of a transsexual. Journal of Human Behavior in the Social Environment, 8, 225-239.

Betancourt, J. R. (2006). Cultural competence and medical education: Many names, many perspectives, one goal. Academic Medicine, 81, 499-501.

Burdge, B. J. (2007). Bending gender, ending gender: Theoretical foundations for social work practice with the transgender community. Social Work, 52, 243-250.

Campinha-Bacote, J. (2002). The process of cultural competence in the delivery of healthcare services: A model of care. Journal of Transcultural Nursing, 13, 181-184.

Carnegie Foundation for Advancement of Teaching. (2010). The Carnegie Classification of Institutions of Higher Education. Retrieved from http://classifications. carnegiefoundation.org

Case, K. A., Kanenberg, H., Erich, S. A., \& Tittsworth, J. (2012). Transgender inclusion in university nondiscrimination statements: Challenging gender-conforming privilege through student activism. Journal of Social Issues, 68, 145-161.

Case, K. A., Stewart, B., \& Tittsworth, J. (2009). Transgender across the curriculum: A psychology for inclusion. Teaching of Psychology, 36, 117-121. 
Clements-Nolle, K., Marx, R., \& Katz, M. (2006). Attempted suicide among transgender persons: The influence of gender-based discrimination and victimization. Journal of Homosexuality, 51, 53-69.

Colvin-Burque, A., Zugazaga, C. B., \& Davis-Maye, D. (2007). Can cultural competence be taught? Evaluating the impact of the SOAP model. Journal of Social Work Education, 43, 223-241.

Cook-Daniels, L., \& Munson, M. (2010). Sexual violence, elder abuse, and sexuality of transgender adults, age 50+: Results of three surveys. Journal of GLBT Family Studies, 6, 142-177.

Council on Social Work Education. (2008). Educational Policy and Accreditation Standards. Retrieved from http://www.cswe.org/File.aspx?id=13780

Cruz, B. C., \& Patterson, J. M. (2005). Cross-cultural simulations in teacher education: Developing empathy and understanding. Multicultural Perspectives, 7, 40-47.

Dean, L., Meyer, I. H., Robinson, K., Sell, R. L., Sember, R., Silenzio, R. M. B., ... Xavier, J. (2000). Lesbian, gay, bisexual, and transgender health: Findings and concerns. Journal of the Gay and Lesbian Medical Association, 4, 102151.

Denny, D., Green, J., \& Cole, S. (2007). Gender variability: Transsexuals, crossdressers, and others. In A. F. Owens \& M. S. Tepper (Eds.), Sexual health (vol. 4, pp. 153-188). Westport, CT: Praeger.

Dispenza, F. W., Watson, L. B., Chung, B., \& Brack, G. (2012). Experience of career-related discrimination for female-to-male transgender persons: A qualitative study. Career Development Quarterly, 60, 65-81.

Ebner, M., \& Holzinger, A. (2007). Successful implementation of user-centered game based learning in higher education: An example from civil engineering. Computers \& Education, 49, 873-890.

Erich, S., Boutté-Queen, N., Donnelly, S., \& Tittsworth, J. (2007). Social work education: Implications for working with the transgender community. Journal of Baccalaureate Social Work, 12, 42-52.

Ezzy, D. (2002). Qualitative analysis: Practice and innovation. London, England: Routledge.

Fontana, A., \& Frey, J. H. (1994). Interviewing: The art of science. In N. K. Denzin \& Y. S. Lincoln (Eds.), Handbook of qualitative research (pp. 361-376). Thousand Oaks, CA: SAGE.

Fredriksen-Goldsen, K. I., Woodford, M. R., Luke, K. P., \& Gutiérrez, L. (2011). Support of sexual orientation and gender identity content in social work education: Results from national surveys of U.S. and Anglophone Canadian faculty. Journal of Social Work Education, 47, 19-35.

Gabbard, W. J., Starks, S. H., Jaggers, J., \& Cappiccie, A. C. (2011). Effective strategies for teaching cultural competency to MSW students in a global society. International Journal of Human and Social Sciences, 6, 204-208.

Gezinski, L. (2009). Addressing sexual minority issues in social work education: A curriculum framework. Advances in Social Work, 10, 103-113.

Grossman, A. H., \& D'Augelli, A. R. (2006). Transgender youth: Invisible and vulnerable. Journal of Homosexuality, 51(1), 111-128.

Grossman, A. H., \& D'Augelli, A. R. (2007). Transgender youth and life-threatening behaviors. Suicide and Life-Threatening Behavior, 37, 527-537. 
Guy-Walls, P. (2007). Exploring cultural competence practice in undergraduate social work education. Education, 127, 569-580.

Hill, D. B., \& Willoughby, B. L. B. (2005). The development and validation of the genderism and transphobia scale. Sex Roles, 53, 531-544.

Hipolito-Delgado, C. P., Cook, J. M., Avrus, E. M., \& Bonham, E. J. (2011). Developing counseling students' multicultural competence through the Multicultural Action Project. Counselor Education \& Supervision, 50(6), 402-421.

Jarvis, P. (2006). Towards a comprehensive theory of human learning. New York, NY: Routledge.

Kerrigan, M. F. (2012). Transgender discrimination in the military: The new don't ask, don't tell. Psychology, Public Policy, and Law, 18(3), 500-518.

Kwon, P., \& Hugelshofer, D. S. (2012). Lesbian, gay, and bisexual speaker panels lead to attitude change among heterosexual college students. Journal of Gay $\&$ Lesbian Social Services, 24(1), 62-79.

Lichtenwalter, S., \& Baker, P. (2010). Teaching note: Teaching about oppression through Jenga: A game-based learning example for social work educators. Journal of Social Work Education, 46, 305-313.

Lombardi, E. L., Wilchins, R. A., Priesing, D., \& Malouf, D. (2001). Gender violence: Transgender experiences with violence and discrimination. The Journal of Homosexuality, 42, 89-101.

Lundahl, B. W. (2008). Teaching research methodology through active learning. Journal of Teaching in Social Work, 28, 273-288.

Mallon, G. P. (1999). Knowledge for practice with transgendered persons. Journal of Gay and Lesbian Social Services, 10(3-4), 1-18.

Maschi, T., Bradley, C., Youdin, R., Killian, M. L., Cleaveland, C., \& Barbera, R. A. (2007). Social work students and the research process: Exploring the thinking, feeling, and doing of research. Journal of Baccalaureate Social Work, 13, 1-12.

McPhail, B. A. (2008). Re-gendering the social work curriculum: New realities and complexities. Journal of Social Work Education, 44, 33-52.

Merton, R. K., Fiske, M., \& Kendall, P. L. (1956). The focused interview. Glencoe, IL: Free Press.

Mezirow, J. (1991). Transformative dimensions of adult learning. San Francisco, CA: Jossey-Bass Publishers.

Morse, J. M. (1994). Designing funded qualitative research. In N. K. Denzin \& Y. S. Lincoln (Eds.), Handbook of qualitative research (pp. 220-235). Thousand Oaks, CA: SAGE.

Nagoshi, J. L., \& Brzuzy, S. (2010). Transgender theory: Embodying research and practice. Affilia, 25, 431-443.

National Association of Social Workers. (1999). Code of ethics (rev. ed.). Washington, DC: NASW.

Rosser, B. R. S., Oakes, J. M., Bockting, W. O., \& Miner, M. (2007). Capturing the social demographics of hidden sexual minorities: An Internet study of the transgender population in the United States. Sexual Research and Social Policy, 4, 50-64.

Rubin, D., Valutis, S., \& Robinson, B. (2010). Social work education and student research projects: A survey of BSW and MSW program directors. Journal of Social Work Education, 46, 39-55. 
Secret, M., Rompf, E. L., \& Ford, J. (2003). Undergraduate research courses: A closer look reveals complex social worker student attitudes. Journal of Social Work Education, 39(3), 411-422.

Sehgal, R., Saules, K., Young, A., Grey, M. J., Gillem, A. R., Nabors, N. A., ... Jefferson, S. (2011). Practicing what we know: Multicultural counseling competence among clinical psychology trainees and experienced multicultural psychologists. Cultural Diversity \& Ethnic Minority Psychology, 17(1), 1-10.

Singh, A. A., \& McKleroy, V. S. (2011). "Just getting out of bed is a revolutionary act": The resilience of transgender people of color who have survived traumatic life events. Traumatology, 17, 34-44.

Stotzer, R. L. (2009). Violence against transgender people: A review of United States data. Aggression and Violent Behavior, 14, 170-179.

Teich, N. M. (2012). Transgender 101: A simple guide to a complex issue. New York, NY: Columbia University Press.

United States Census Bureau. (2011). Retrieved from http://quickfacts.census.gov/

Van Den Bergh, N., \& Crisp, C. (2004). Defining culturally competent practice with sexual minorities: Implications for social work education and practice. Journal of Social Work Education, 40, 221-238.

Van Soest, D., Canon, R., \& Grant, D. (2000). Using an interactive website to educate about cultural diversity and societal oppression. Journal of Social Work Education, 36, 463-479.

Vincent, N. J. (2012). Exploring the integration of social justice into social work research curricula. Journal of Social Work Education, 48(2), 205-222.

Walinsky, D., \& Whitcomb, D. (2010). Using the ACA competencies for counseling transgender clients to increase rural transgender well-being. Journal of LGBT Issues in Counseling, 4, 160-175.

Wallace, B. C. (2000). A call for change in multicultural training at graduate schools of education: Educating to end oppression and for social justice. Teachers College Record, 102, 1086-1112.

Warde, B. (2012). The cultural genogram: Enhancing the cultural competency of social work students. Social Work Education, 31(5), 570-586.

Winter, S., Webster, B., \& Cheung, P. K. E. (2008). Measuring Hong Kong undergraduate students' attitudes towards transpeople. Sex Roles, 59(9/10), 670-683. 